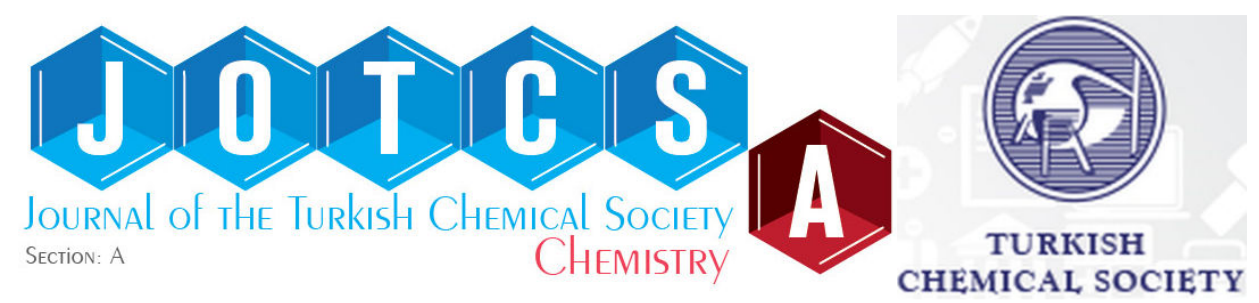

\title{
Chemical Characterization of Lavandula angustifolia Mill. as a Phytocosmetic Species and Investigation of its Antimicrobial Effect in Cosmetic Products
}

\author{
Aslıhan Cesur Turgut ${ }^{1 *}$, Fatih Mehmet Emen², Hale Seçilmiş Canbay ${ }^{3}$, Ruken Esra \\ Demirdöğen ${ }^{4}$, Neslihan Çam ${ }^{5}$, Derya Kılıç6, Tuncay Yeşilkaynak ${ }^{7}$
}

\begin{abstract}
${ }^{1}$ Mehmet Akif Ersoy University, Scientific and Technological Application and Research Center/ Tefenni Vocational School, 15100, Burdur, Turkey, ${ }^{2}$ Mehmet Akif Ersoy University Faculty of Science, Department of Chemistry, 15100, Burdur, Turkey, ${ }^{3}$ Mehmet Akif Ersoy University, Scientific and Technological Application and Research Center, 15100, Burdur,

Turkey, ${ }^{4}$ Cankiri Karatekin University, Faculty of Science, Department of Chemistry, 18100, Cankiri, Turkey, ${ }^{5}$ Laber Kimya Ar-Ge San. Tic., Izmir, Turkey, ${ }^{6}$ Mehmet Akif Ersoy University Faculty of Science, Department of Chemistry, 15100, Burdur, Turkey. ${ }^{7}$

Kahramanmaras Sutcu Imam University, Afsin Vocational School, Kahramanmaras, Turkey.
\end{abstract}

\begin{abstract}
The content of the extracts obtained from Lavandula angustifolia, which were grown in Burdur Örtülü locality, was determined via HPLC and GC-MS analysis and the anti-microbial effect of the essential oil L. angustifolia was also investigated. The dried flowers of $L$. angustifolia were extracted and the essential oil was distilled from the remaining part. Various phenolic compounds in the extract were quantitatively determined by HPLC. Quantitatively caffeic acid, rosmarinic acid, and 4-hydroxybenzoic acids were the most abundant phenolic acids in the content in decreasing order. 31 different compounds were determined by GC-MS analysis: Linalool and linalyl acetate have the highest concentration. Anti-microbial effects of the essential oil of L. angustifolia were determined against the most frequently encountered microorganisms in the cosmetics: Candida albicans, Staphylococcus aureus, Pseudomonas aeruginosa, and Aspergillus brasiliensis. It was observed that the essential oil L. angustifolia could completely remove the contamination caused by the microorganisms as of the $14^{\text {th }}$ day. According to the results it is concluded that the essential oil of $L$. angustifolia, can be used either directly or incorporated into the cosmetics without the necessity for any other extra preservative against the above mentioned microrganisms.
\end{abstract}

Keywords: Lavandula angustifolia Mill.; cosmetic; phenolic compounds; essential oil; antimicrobial activity.

Submitted: July 04, 2016. Revised: November 24, 2016. Accepted: November 25, 2016.

Cite this: Cesur Turgut A, Emen F, Seçilmiş Canbay H, Demirdöğen R, Çam N, Kılıç $D$, et al. Chemical Characterization of Lavandula angustifolia Mill. as a Phytocosmetic Species and Investigation of its Antimicrobial Effect in Cosmetic Products. JOTCSA. 2017;4(1):283-98.

DOI: To be assigned.

*Corresponding author. E-mail: ascesur@gmail.com. 


\section{INTRODUCTION}

In the last years, usage of aromatic plants in the perfumery, food, and cosmetics industries as the principal raw material as well as its usage in many other fields have increased the demand for medicinal and aromatic plants. Especially the methods, which are named as return to nature, have increased the interest in these plants both in Turkey and in other countries in the world [1].

Lavender (Lavandula sp.) is a very valuable essential oil plant from the Lamiaceae family. There are 39 lavender species (Lavandula sp.) most of which have Mediterranean origin and among them, three have high commercial value. While the essential oil quality of the lavender species (British lavender) is high the lavandin species (hybrid lavender) have high essential oil yield [2, 3]. It plays an important role in the pharmacology and perfumery industries since it contains essential and aromatic oils [4]. 1.8-2 billion dollarworth of essential oil is exported each year in the world and lavender oil constitutes 50 million dollars of this export [5, 6, 7]. The three commercial lavender species are Lavender (Lavandula angustifolia Mill. $=$ L. officinalis $\mathrm{L}$. $=$ L. vera DC), Lavandin (Lavandula intermedia Emeric ex Loisel. = L. hybrida L.) and Spike Lavender (Lavandula spica $=$ L. latifolia Medik.). While the essential oil quality of the Lavender types, which are named as British lavender, is high the essential oil quantity of lavandin, which is named as hybrid lavender [8].

The most important essential oil components of lavender oil are linalyl acetate, linalool, and cineol. Among them, linalyl acetate is the most important component which determines the quality of the lavender oil [9]. There are many studies which indicate that L. angustifolia mostly contains linalool and linalyl acetate as essential oil component in essential oil obtained via water vapor distillation of the flowers of $L$. angustifolia $[10,11$, 12]. Due to linalool and linalyl acetate, both of which are present in the plant, lavender is used in production of perfume, skin cleaning lotion, bath soap with odor and bath foams in the cosmetics industry $[13,14,15]$. Lavender and its ethanolic extract have high antioxidant activity and its content is rich in phenolic compounds. It is thought that this effect arises from the protective effect that phenolic compounds show against oxidative damage which is caused by the free radicals. Moreover, it is indicated that lavender inhibits bacterial growth $[9,16]$.

Cosmetic products are not sterile and are open to the growth of microorganism contamination any time. When these products are studied from the microbiological perspective, since they are not produced under aseptic conditions, microorganisms which are not pathogens are observed. Cosmetic products containing pathogenic 
microorganisms would put the health of people who use them in danger rather than beautifying them and would either degrade the products or cause diseases. The dangers, which cosmetic products cause, have attracted the attention of those working in this field and intensive studies on this subject [17]. According to the American Pharmacopoeia, Escherichia coli, Pseudomonas aeruginosa, Staphylococcus aureus and Salmonella typhimurium, Candida albicans and Aspergillus niger are microorganisms which should not be found in cosmetic products [18]. Staphylococcus aureus is one of the most common bacterial skin pathogen found in creams. Presence of these bacteria in creams intensively may cause skin and mucosal infections such as inflammatory skin disease (impetigo), follicular inflammation, and abscess. Infection starts when Staphylococcus degrades in the dermal mucosal barrier and enters into the tissues or into the bloodstream $[19,20]$. It is reported that the active of the $70 \%$ of the skin infections seen in children is $S$. aureus [21]. It is reported that ocular infections are commonly seen in patients who use eye drops. Nosocomial infections and epidemics arising from usage of products contaminated with $P$. aeruginosa are reported [22]. Glycerin used in creams and lotions can be metabolized by microorganisms (especially by Bacillus, Staphyloccocus and Micrococcus) [23]. Cosmetic products contaminated by $C$. albicans can cause dermatitis [24]. The creams produced by the Ukranian Company Effect which are determined to contain C. albicans were collected by the end of 2006 upon notification of Estonia [25].

In the present study, our aim was to examine the content of the extracts obtained from Lavandula angustifolia, which were grown in Burdur Örtülü locality and also investigate the anti-microbial effect of the essential oil of $L$. angustifolia. For this purpose, various phenolic compounds were detected in the extracts of Lavender (Lavandula angustifolia Mill.) and essential compounds were also detected in its essential oil.

\section{MATERIALS AND METHODS}

\section{Chemical Materials}

Caffeic acid, p-coumaric acid, and rosmarinic acid were purchased from Sigma, 3,4dihydroxybenzoic acid, chlorogenic acid, and ferulic acid were purchased from Aldrich, 4hydroxybenzoic acid, cinnamic acid, and ethanol (absolute for analysis) were purchased from Merck, hexane (for HPLC $\geq 97.00$ ) and methanol (HPLC grade $\geq 99.9 \%$ ) were purchased from Sigma-Aldrich, vanilic acid and apigenin were purchased from Fluka, formic acid (analytical reagent grade) was purchased from Fisher Chemical and gallic acid was purchased from Pancreac. 


\section{Plant Material (Sampling)}

Lavenders (Lavandula angustifolia Mill.) collected from Burdur Örtülü locality $\left(37.7167^{\circ} \mathrm{N}-30.2833^{\circ} \mathrm{E}\right.$ and $959 \mathrm{~m}$ above sea level) were used. $2000 \mathrm{~g}$ of lavender sample has been dried in the shade after the harvest and the dry flowers were separated from their stems.

\section{Solvent Extraction}

Dry flowers separated from their stems were extracted for analysis of their phenolic content. 2-g-sample was dried, powdered and extracted with $10 \mathrm{~mL}$ of $96 \%$ ethanol for $24 \mathrm{~h}$ in water bath at $45^{\circ} \mathrm{C}$. This mixture is centrifuged at $4000 \mathrm{rpm}$ for 5 minutes. Supernatant was concentrated with the rotary evaporator at $45^{\circ} \mathrm{C}$ until complete dryness and dissolved in mobile phase [26].

\section{Clevenger extraction}

$2000 \mathrm{~g}$ stemless dry lavender flowers were weighed. Then the flowers were submitted to hydrodistillation with a Clevenger-type apparatus. As a result of distillation, essential oil yield was found $4.2 \%$.

\section{Instrumentation}

Chromatographic analyses were performed using a Shimadzu reversed-phase highperformance liquid chromatography (RP-HPLC) equipped with diode-array detector (DAD). RP-HPLC analysis were done using a 20ACBM system controller, SPD-M20A diode array detector, CTO-10ASVp column oven, SIL 20ACHT autosampler, and a LC20 AT pump. The data were performed using the LC Solution software. The chromatographic separations were achieved on Agilent Eclipse C18 column (250*4,6 mm i.d., $5 \mu \mathrm{m})$ the eluates were detected at $280 \mathrm{~nm}$ and $320 \mathrm{~nm}$. Analysis of phenolics in Lavandula was achieved by RP-HPLC with gradient elution. The mobile phase used was $3 \%$ formic acid in (A) water vs (B) methanol. The elution gradient applied at a flow rate of $0.8 \mathrm{~mL} \mathrm{~min} \mathrm{~m}^{-1}$ was: $93 \% A / 7 \%$ B for $3 \mathrm{~min}, 72 \% A / 28 \% B$ in $28 \mathrm{~min}, 67 \% A / 33 \% B$ in $60 \mathrm{~min}$, $58 \% \mathrm{~A} / 42 \% \mathrm{~B}$ in $62 \mathrm{~min}, 50 \% \mathrm{~A} / 50 \% \mathrm{~B}$ in $70 \mathrm{~min}, 30 \% \mathrm{~A} / 70 \% \mathrm{~B}$ in $75 \mathrm{~min}, 93 \% \mathrm{~A} / 7 \% \mathrm{~B}$ in $80 \mathrm{~min}$. Samples were dissolved in mobile phase, and $20 \mu \mathrm{L}$ of this solution was injected into the column. The column temperature was set at $30^{\circ} \mathrm{C}$. In the HPLC analysis the method of Gomes et al. (1999) was modified and used [27]. The volatile compounds were analyzed by using a gas chromatograph 7890 A coupled to a mass spectrometer series MSD 5975 C, (Agilent Technologies) and volatiles were resolved on a CP WAX 52 $\mathrm{CB}$ capillary column ( $50 \mathrm{~m} * 0.32 \mathrm{~mm}$ ID, $\mathrm{df}: 1.2 \mu \mathrm{m})$ purchased from Agilent. The carrier gas was helium, at a flow rate of $1.2 \mathrm{~mL} / \mathrm{min}$. The temperature program for the $\mathrm{GC}$ was as follows; $60{ }^{\circ} \mathrm{C}$ initial temperature, after waiting for 2 minutes at $60{ }^{\circ} \mathrm{C}$ to 
increase $220{ }^{\circ} \mathrm{C}$ with $2{ }^{\circ} \mathrm{C} / \mathrm{min}$, after reaching this temperature the temperature was kept constant for 20 minutes. The injection was performed in the split mode (20:1). The injection volume was $1 \mu \mathrm{L}$. Injector temperature was $240{ }^{\circ} \mathrm{C}$ The GC-MS interface was heated at $240^{\circ} \mathrm{C}$. MS ion source temperature was $230^{\circ} \mathrm{C}$ and $\mathrm{MS}$-quadrupole was $150{ }^{\circ} \mathrm{C}$. The electron impact energy was set at $70 \mathrm{eV}$, and data were collected in the range of 30500 atomic mass units (amu). Compounds' identification was based on mass spectra by comparison with MS spectral database from Wiley. The integrations were performed with MSDCHEM software [28].

\section{Microorganisms and growth culture}

Antimicrobial effects of Lavender essential oil on bacteria-yeast and mold strains were investigated. When choosing the microorganisms, the frequently encountered species in the contaminated creams such as Candida albicans, Staphylococcus aureus, Pseudomonas aeruginosa, and Aspergillus brasiliensis were preferred. The methods used in preparation of reference cultures are given in Table 1 and the working cultures, can be seen in Table 2, prior to inoculation, are given below. The protective activity of Lavender oil is determined via challenge test and according to TS EN ISO 11930:2012 standard which is an international method [53]. According to this method the sample was weighed $(\mathrm{g} / \mathrm{mL})$ and the bacteria Staphylococcus aureus and Pseudomonas aeruginosa and the fungi Candida albicans and Aspergillus brasiliensis were inoculated in the sample at a known level. Following this the samples were incubated in the acclimatization cabin at 25 ${ }^{\circ} \mathrm{C}$ for 28 days. On the $7^{\text {th }}$ and $14^{\text {th }}$ days of incubation and at the end of incubation, samples were analyzed and the number of microorganisms was determined.

Table 1. Preparation of the Reference Stock Cultures.

\begin{tabular}{lll}
\hline Reference Strains & Method & Broth Medium Used \\
\hline Staphylococcus aureus & Plate & Tryptic Soy Agar \\
ATCC 6538/ Lot 3221505 & & \\
$\begin{array}{l}\text { Pseudomonas aeruginosa ATCC 9027/ Lot 3270513 } \\
\text { Candida albicans }\end{array}$ & Plate & Tryptic Soy Agar \\
$\begin{array}{l}\text { ATCC 10231/ Lot 8067507 } \\
\text { Aspergillus brasiliensis }\end{array}$ & Plate & Sabouraud 4\% Dextrose \\
ATCC 16404/ Lot 3175110 & Plate & Agar + Supplement \\
\hline
\end{tabular}


Table 2. Preparation of Working Cultures.

\begin{tabular}{lll}
\hline Analysis & Method & Broth Medium Used \\
\hline Staphylococcus aureus & Enrichment and Line & Baird-Parker Agar Staphylococcus \\
ATCC 6538 & inoculation in solid broth & Selective Agar \\
Pseudomonas aeruginosa ATCC & Enrichment and Line & Cetrimide Agar Pseudomonas \\
9027 & inoculation in solid broth & Selective Agar \\
Candida albicans & Enrichment and Line & Sabouraud 4\% Dextrose Agar + \\
ATCC 10231 & inoculation in solid broth & Supplement \\
Mould- Yeast & Diffusion Plate & Sabouraud 4\% Dextrose Agar \\
Total aerobic mesophilic & Diffusion Plate & Tryptic Soy Agar With Polysorbate \\
microorganisms & & 80 And Lecithin \\
\hline
\end{tabular}

\section{RESULTS AND DISCUSSION}

\section{HPLC Results}

Eleven different phenolic compounds were determined via HPLC analysis as it can be seen in Table 3. The antimicrobial phytochemicals are collected in five groups as phenolics, terpenoids-essential oils, alkaloids, lectins-polypeptides and polyacetylenes [29]. Phenolics constitute the largest group among the vegetative antimicrobial agents [30]. The phenolic compounds determined in the lavender extract are gallic acid, 3,4dihydroxybenzoic acid, 4-hydroxybenzoic acid, chlorogenic acid, vanillic acid, caffeic acid, p-coumaric acid, ferulic acid, apigenin, rosmarinic acid, and cinnamic acid can be seen in Table 4. Its standard chromatogram is given in Figure 1 and the chromatogram of its extract is presented in Figure 2. It is well known that the polyphenols show goof antibacterial effect [31]. High concentrations of phenolic compounds are toxic both for the plants and the microorganisms $[32,33]$. 
Table 3. Concentration of 11 phenolic acids in Lavender sample.

\begin{tabular}{|c|c|c|c|c|c|c|c|c|c|c|c|}
\hline Sample & $\begin{array}{l}\text { Gallic } \\
\text { Acid }\end{array}$ & $\begin{array}{c}\text { 3,4- } \\
\text { dihydroxy } \\
\text { benzoic } \\
\text { Acid }\end{array}$ & $\begin{array}{c}\text { 4- } \\
\text { hydroxybenzoic } \\
\text { Acid }\end{array}$ & $\begin{array}{c}\text { Chlorogenic } \\
\text { Acid }\end{array}$ & $\begin{array}{c}\text { Vanillic } \\
\text { Acid }\end{array}$ & $\begin{array}{c}\text { Caffeic } \\
\text { Acid }\end{array}$ & $\begin{array}{c}\text { p- } \\
\text { Coumaric } \\
\text { Acid }\end{array}$ & $\begin{array}{c}\text { Ferulic } \\
\text { Acid }\end{array}$ & Apigenin & $\begin{array}{c}\text { Rosmarinic } \\
\text { Acid }\end{array}$ & $\begin{array}{c}\text { Cinnamic } \\
\text { Acid }\end{array}$ \\
\hline Lavender & $* 0.14$ & 3.37 & 10.70 & 7.41 & 0.67 & 15.20 & 5.03 & 0.18 & 7.80 & 10.13 & 0.98 \\
\hline
\end{tabular}

*All the values in the same line are given as $\mu \mathrm{g} / \mathrm{g}$.

Table 4. LOD values, wavelengths, retention time (RT), and linear regression coefficients ( $\left.R^{2}\right)$ for phenolic compounds.

\begin{tabular}{|c|c|c|c|c|c|c|c|c|c|c|c|}
\hline & $\begin{array}{l}\text { Gallic } \\
\text { Acid } \\
\text { (1) }\end{array}$ & $\begin{array}{c}\text { 3,4-dihydroxy } \\
\text { benzoic Acid } \\
\text { (2) }\end{array}$ & $\begin{array}{c}\text { 4- } \\
\text { hydroxybenzoic } \\
\text { Acid (3) }\end{array}$ & $\begin{array}{c}\text { Chlorogenic } \\
\text { Acid (4) }\end{array}$ & $\begin{array}{l}\text { Vanillic } \\
\text { Acid (5) }\end{array}$ & $\begin{array}{l}\text { Caffeic } \\
\text { Acid } \\
(6)\end{array}$ & $\begin{array}{c}\text { p- } \\
\text { Coumaric } \\
\text { Acid (7) }\end{array}$ & $\begin{array}{c}\text { Ferulic } \\
\text { Acid } \\
(8)\end{array}$ & $\begin{array}{l}\text { Apigenin } \\
(9)\end{array}$ & $\begin{array}{c}\text { Rosmarin } \\
\text { ic } \\
\text { Acid (10) }\end{array}$ & $\begin{array}{l}\text { Cinnamic } \\
\text { Acid (11) }\end{array}$ \\
\hline LOD (mg/L) & 0.19 & 0.027 & 0.036 & 0.017 & 0.019 & 0.019 & 0.022 & 0.021 & 0.010 & 0.016 & 0.016 \\
\hline $\begin{array}{l}\text { Detection } \\
\text { wavelength } \\
(\mathrm{nm})\end{array}$ & 280 & 280 & 280 & 320 & 320 & 280 & 320 & 320 & 320 & 320 & 280 \\
\hline $\begin{array}{l}\mathrm{RT} \\
\mathrm{R}^{2}\end{array}$ & $\begin{array}{c}7.8 \\
0.999\end{array}$ & $\begin{array}{l}12.2 \\
0.999\end{array}$ & $\begin{array}{l}16.9 \\
0.999\end{array}$ & $\begin{array}{l}19.4 \\
0.999\end{array}$ & $\begin{array}{l}21.7 \\
0.999\end{array}$ & $\begin{array}{c}24 \\
0.999\end{array}$ & $\begin{array}{l}29.3 \\
0.999\end{array}$ & $\begin{array}{l}34.7 \\
0.999\end{array}$ & $\begin{array}{l}64.1 \\
0.999\end{array}$ & $\begin{array}{l}66.7 \\
0.999\end{array}$ & $\begin{array}{l}70.7 \\
0.999\end{array}$ \\
\hline
\end{tabular}




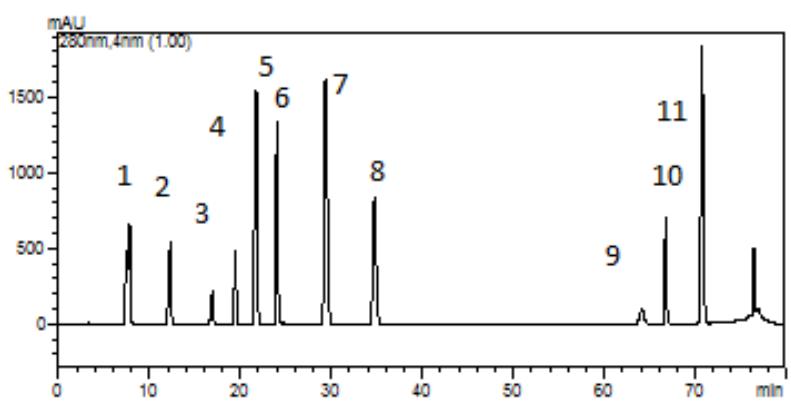

Figure 1. HPLC chromatogram of standard mixtures. 1. Gallic acid, 2. 3,4dihydroxybenzoic acid, 3. 4-hydroxybenzoic acid, 4. chlorogenic acid, 5. vanillic acid, 6. caffeic acid, 7. p-coumaric acid, 8. ferulic acid, 9. apigenin, 10. rosmarinic acid, 11. cinnamic acid. (Agilent Eclipse C18 column (250*4.6 mm i.d., $5 \mu \mathrm{m}$ ), flow rate: $0.8 \mathrm{~mL}$ min $^{-1}$, wavelength: $280 \mathrm{~nm}$ )

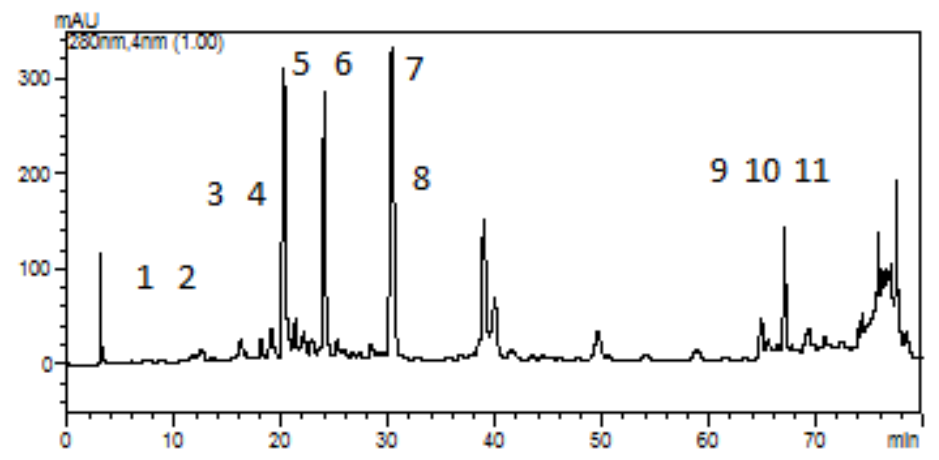

Figure 2. HPLC chromatogram of the sample. 1. Gallic acid, 2. 3,4-dihydroxybenzoic acid, 3. 4-hydroxybenzoic acid, 4. chlorogenic acid, 5. vanillic acid, 6. caffeic acid, 7. pcoumaric acid, 8. ferulic acid, 9. apigenin, 10. rosmarinic acid, 11. cinnamic acid. (Agilent Eclipse C18 column (250*4.6 mm i.d., $5 \mu \mathrm{m}$ ), flow rate: $0.8 \mathrm{~mL} \mathrm{~min}^{-1}$, wavelength: 280 $\mathrm{nm})$.

\section{GC-MS Results}

The Lavender essential oil is reported to be rich in linalyl acetate and linalool in the studies $[34,35]$. The results of the analysis that we made also support these findings. Our results are given in Table 5.

Linalool, linalyl acetate, and a-terpineol have the highest ratio with $42.215 \%, 23.116 \%$ and $4.912 \%$, respectively. The results can also be seen in Figure 3 as the chromatogram of the samples.

Lavender oil inhibited the growth of C. Albicans. Many researchers have also reported that especially essential oils rich in phenolics, aldehydes, and alcohols are effective in inhibiting pathogenic microorganisms and in preventing degradation [37]. Therefore, phenolic compounds are natural alternative to the synthetic antimicrobials used in the cosmetics, food and pharmaceutical industries [38] and they can be active even at low concentrations [37]. It is reported that linalool and a-terpineol have strong antimicrobial 
activity against periodontopathic and cariogenic bacteria [36]. Furthermore, the antibacterial activity of lavender oil and its main components; i.e. 1,8-cineol, linalool, linalyl acetate, limonene, a-pinene, and $\beta$-pinene have been assayed against the human pathogenic bacteria and they have been successful [46]. These results are consistent with our findings.

Table 5. Essential oil composition of Lavender.

\begin{tabular}{|c|c|c|c|}
\hline No & Component & $\mathbf{R T}^{*}$ & Ratio(\%) \\
\hline 1. & a-pinene & 4.2 & 0.028 \\
\hline 2. & Camphene & 4.9 & 0.046 \\
\hline 3. & $\beta$-pinene & 5.5 & 0.019 \\
\hline 4. & $\beta$-myrcene & 6.2 & 0.341 \\
\hline 5. & a-terpinene & 6.5 & 0.007 \\
\hline 6. & Limonene & 6.7 & 0.234 \\
\hline 7. & 1,8 cineol & 6.9 & 0.677 \\
\hline 8. & Cymene & 7.1 & 0.955 \\
\hline 9. & 3-octanone & 7.4 & 0.163 \\
\hline 10. & Acetic acid hexyl ester & 7.5 & 0.257 \\
\hline 11. & a -terpinolene & 7.7 & 0.156 \\
\hline 12. & 3-octayl acetate & 8.2 & 0.089 \\
\hline 13. & n-hexyl isobutyrate & 8.28 & 0.228 \\
\hline 14. & 1-hexene & 8.3 & 0.033 \\
\hline 15. & 1-octen 3 yl acetate & 8.5 & 0.193 \\
\hline 16. & 3-octanol & 8.6 & 0.071 \\
\hline 17. & Butanoic acid hexyl ester & 8.9 & 1.323 \\
\hline 18. & Hexyl -2-methyl butanoate & 9 & 0.231 \\
\hline 19. & Linalool oxide & 9.1 & 0.592 \\
\hline 20. & Linalool & 9.8 & 42.215 \\
\hline 21. & Linalyl acetate & 10 & 23.116 \\
\hline 22. & Cyclohexanone & 10.1 & 2.053 \\
\hline 23. & Neryl acetate & 10.3 & 0.211 \\
\hline 24. & Trans caryphyllene & 10.4 & 0.935 \\
\hline 25. & Farnesene & 10.7 & 0.28 \\
\hline 26. & a-terpineol & 11 & 4.912 \\
\hline 27. & Borneol & 11.1 & 3.394 \\
\hline 28. & Geranyl acetate & 11.2 & 0.935 \\
\hline 29. & Nerol & 11.4 & 4.229 \\
\hline 30. & Geraniol & 12.2 & 2.975 \\
\hline 31. & $\begin{array}{l}\text { Caryophyllene oxide } \\
\text { TOTAL } \\
\text { Unknown }\end{array}$ & 14.5 & $\begin{array}{l}4.5 \\
95.398 \\
4.602\end{array}$ \\
\hline
\end{tabular}

* RT: Retention time

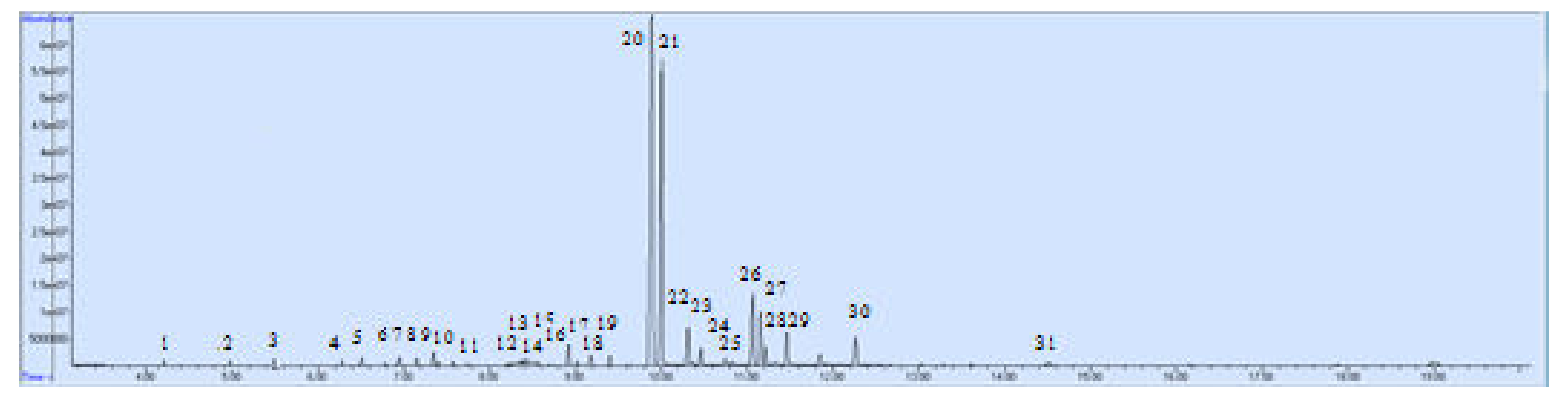

Figure 3. GC-MS Chromatogram of the sample. 


\section{Microbiological Results}

According to the ISO 11930 standard challenge test was applied on lavender essential oil for 28 days and their logarithmic decreases were evaluated can be seen in Table 6-8.

Table 6. Microbial activity test performed according to the ISO standard.

\begin{tabular}{lllll}
\hline \multicolumn{1}{c}{ Parameter } & Unit & $\begin{array}{c}\text { Results of } \\
\text { the } \\
\text { Analysis }\end{array}$ & $\begin{array}{c}\text { Standard } \\
\text { No }\end{array}$ & Limit Value \\
\hline Total aerobic mesophilic microorganism & $\mathrm{cfu} / \mathrm{g}$ & $<1000 \mathrm{cfu} / \mathrm{g}$ & ISO 21149 & $<1000 \mathrm{cfu} / \mathrm{g}$ \\
Candida albicans & $\mathrm{cfu} / \mathrm{g}$ & Negative & ISO 18416 & Negative \\
Staphylococcus aureus & $\mathrm{cfu} / \mathrm{g}$ & Negative & ISO 22718 & Negative \\
Pseudomonas aeruginosa & $\mathrm{cfu} / \mathrm{g}$ & Negative & ISO 22717 & Negative \\
Mold-Yeast & $\mathrm{cfu} / \mathrm{g}$ & $<1000 \mathrm{cfu} / \mathrm{g}$ & ISO 16212 & $<1000 \mathrm{cfu} / \mathrm{g}$ \\
\hline
\end{tabular}

The antimicrobial activity of the essential oil studied on the microorganism strains was found to be pretty high. The results of the total aerobic mesophilic microorganism and Total Mold-Yeast counting, which determine the microbial quality of the oil were found to be coherent with the limit values. Moreover, Candida albicans, Staphylococcus aureus, Pseudomonas aeruginosa, and pathogenic microrganisms were not encountered in the analysis. The microbiologic quality of the product is sufficient for its usage in production of cosmetics can be seen in Table 6-8. In the analysis the ISO standards were applied in the microbiology of cosmetics were used and the analysis were made in an accredited laboratory.

Table 7. Logarithmic Evaluation Table.

\begin{tabular}{|c|c|c|c|c|c|c|c|}
\hline \multirow{2}{*}{ Microorganism } & \multicolumn{2}{|c|}{$1^{\text {st }}$ Hour } & \multicolumn{3}{|c|}{$\begin{array}{l}7^{\text {th }} \\
\text { Day }\end{array}$} & \multirow{2}{*}{$\begin{array}{c}14^{\text {th }} \\
\text { Day } \\
\text { CFU/g } \\
\end{array}$} & \multirow{2}{*}{$\begin{array}{c}28^{\text {th }} \\
\text { Day } \\
\text { CFU/g }\end{array}$} \\
\hline & CFU/g & $\begin{array}{l}\log \\
\text { CFU/g }\end{array}$ & CFU/g & $\begin{array}{l}\log \\
\text { CFU/g }\end{array}$ & $\begin{array}{l}\log \\
\text { reduction }\end{array}$ & & \\
\hline $\begin{array}{l}\text { Staphylococcus aureus } \\
\text { ATCC } 6538 \text { / Lot } 3221505\end{array}$ & $1.0 \mathrm{E}+06$ & 6.00 & $9.8 \mathrm{E}+01$ & 2.0 & 4.01 & $<10$ & $<10$ \\
\hline $\begin{array}{l}\text { Pseudomonas aeruginosa } \\
\text { ATCC } 9027 / \text { Lot } 3270513\end{array}$ & $1.2 \mathrm{E}+06$ & 6.09 & $1.5 \mathrm{E}+02$ & 2.2 & 3.93 & $<10$ & $<10$ \\
\hline $\begin{array}{l}\text { Candida albicans } \\
\text { ATCC } 10231 / \text { Lot } 8067507\end{array}$ & $2.3 E+05$ & 5.36 & $6.5 \mathrm{E}+01$ & 1.8 & 3.55 & $<10$ & $<10$ \\
\hline $\begin{array}{l}\text { Aspergillus brasiliensis } \\
\text { ATCC } 16404 / \text { Lot } 3175110\end{array}$ & $1.5 \mathrm{E}+04$ & 4.18 & $1.5 \mathrm{E}+01$ & 1.2 & 3.00 & $<10$ & $<10$ \\
\hline
\end{tabular}

Many antimicrobial studies were made regarding $L$. angustifolia on various microorganisms $[34,35,39-48]$ and our findings supported these results. 
Table 8. Result Control Table.

\begin{tabular}{|c|c|c|c|c|c|c|c|c|}
\hline \multicolumn{9}{|c|}{ Log decrease values $(R x=\lg N 0-\lg N x)$ required a } \\
\hline Microorganisms & & cteria & & C. $a$ & icans & & A.br: & siliensis \\
\hline Sampling Time & T7 & T14 & $\mathbf{T 2 8}$ & T7 & T14 & T28 & $\mathbf{T 1 4}$ & T28 \\
\hline Criteria A & $\geq 3$ & $\begin{array}{c}\geq 3 \\
\text { and } \mathrm{NI}^{\mathrm{b}}\end{array}$ & $\begin{array}{l}\geq 3 \\
\text { and } \\
\text { NI }\end{array}$ & $\geq 1$ & $\begin{array}{c}\geq 1 \\
\text { and } \\
\text { NI }\end{array}$ & $\begin{array}{l}\geq 1 \\
\text { and } \\
\text { NI }\end{array}$ & $\geq 0^{c}$ & $\geq 1$ \\
\hline Criteria B & Not applied & $\geq 3$ & $\begin{array}{c}\geq 3 \\
\text { and } \\
\mathrm{NI}\end{array}$ & Not applied & $\geq 1$ & $\begin{array}{l}\geq 1 \\
\text { and } \\
\text { NI }\end{array}$ & $\geq 0$ & $\begin{array}{c}\geq 0 \\
\text { and NI }\end{array}$ \\
\hline
\end{tabular}

a: In this test, 0,5 log deviation are evaluated as acceptable.

$\mathrm{b}: \mathrm{NI}$ : No increase in the time since the previous count

$c: R x=0 \lg N O=$ When $\operatorname{lgn} x$ (no increase after the first count)

Lavender (Lavandula angustifolia) essential oil has been pretty effective on the mentioned microorganisms (Table7-8) and as of the $14^{\text {th }}$ day, they could eliminate contamination completely.

\section{CONCLUSION}

The content of the essential oils extracted from Lavandula angustifolia, which were grown in Burdur Örtülü locality, was determined via HPLC and GC-MS analysis. Furthermore, the anti-microbial effect of the essential oil $L$. angustifolia was also investigated. To obtain lavandula oil, Clevenger and solvent extraction methods were used. Various phenolic compounds in the extracts were quantitatively determined by HPLC.

Eleven different phenolic compounds, which are gallic acid, 3,4-dihydroxybenzoic acid, 4hydroxybenzoic acid, chlorogenic acid, vanillic acid, caffeic acid, p-coumaric acid, ferulic acid, apigenin, rosmarinic acid, and cinnamic acid were determined via HPLC analysis. In a quantitative sense, caffeic acid, rosmarinic acid, and 4-hydroxybenzoic acids were the most abundant phenolic acids in the content in decreasing order. It is known that the phenolic compounds in lavender extract show antimicrobial effect. Thirty-one different volatile compounds were determined by GC-MS analysis. It was found that linalool and linalyl acetate have the highest concentration. Anti-microbial effects of the essential oil of L. angustifolia were determined against the most frequently encountered microorganisms in the cosmetics such as Candida albicans, Staphylococcus aureus, Pseudomonas aeruginosa, Aspergillus brasiliensis. According to our results it is revealed that the essential oil, L. angustifolia, can be used either directly or incorporated into the cosmetics without the necessity for any other extra preservative against the 
microrganisms mentioned above. Also, it was found that the essential oil of $L$. angustifolia completely removed the contamination caused by some microorganisms.

\section{REFERENCES}

1. Kan Y, Uçan US, Kartal M, Altun ML, Aslan S, Sayar E, Ceyhan T. GC-MS Analysis and Antibacterial Activity of Cultivated Satureja cuneifoliaTen. Essential Oil, Turkish Journal of Chemistry. 2006; 30: 253-259. URL: http://journals.tubitak.gov.tr/chem/issues/kim-06-302/kim-30-2-14-0506-6.pdf

2. Guenther, E., Haagen-Smit, A., Langenau, E., \& Urdang, G. E. Guenther, D. Althausen, and F. Sterrett (vol. 2); E. Guenther (vols. 3-6). 1948-1952. The Essential Oils, 6. ISBN: 088275073997808827507360882751638978088275163408827507479780882750743 08827509259780882750927.

3. Kara, N., Baydar, H., 2013. Determination of lavender and lavandin cultivars (Lavandula sp.) containing high quality essential oil in Isparta, Turkey. Turk J Field Crops, 18, 58-65. URL: http://www.field-crops.org/assets/pdf/product51d3c571594ef.pdf

4. Seçmen Ö, Gemici Y, Görk G, Bekat L, Leblebici E. Tohumlu Bitkiler Sistematiği. Ege Üniversitesi Fen Fakültesi Kitaplar Serisi No: 116. İzmir. 2000. ISBN: 9789754830286.

5. Baydar H. Tıbbi, Aromatik ve Keyf Bitkileri Bilimi ve Teknolojisi (2. Baskı). Süleyman Demirel Üniversitesi Yayın No: 51. Isparta. 2007. 288 s. ISBN: $9757929794,9789757929796$.

6. Boelens MH. Chemical and sensory evaluation of Lavandula oils. Perfum. Flavor. 1995; 20: 2351. URL: http://kbd.kew.org/kbd/detailedresult.do?id=126386

7. Kara N. Uçucu Yağ Üretimine Uygun Lavanta (Lavandula sp.) Çeşitlerinin Belirlenmesi Ve Mikroçoğaltım Olanaklarının Araştırılması. Süleyman Demirel Üniversitesi, Fen Bilimleri Enstitüsü, Tarla Bitkileri Anabilim Dalı, Doktora Tezi. 2011; 178p. URL: http://ulusaltezmerkezi.com/ucucu-yag-uretimine-uygun-lavanta-lavandula-sp-cesitlerininbelirlenmesi-ve-mikrocogaltim-olanaklarinin-arastirilmasi/2/

8. Beetham J, Entwistle T. The Cultivated Lavenders. Royal Botanic Gardens, Melbourne. 1982. URL:

https://scholar.google.com.tr/scholar?q=The+Cultivated+Lavenders\&btnG $=\&$ hl $=$ tr\&as_sdt $=0$ $\% 2 \mathrm{C5}$

9. Hui L, He L, Huan L, Lan LX, Guo ZA. Chemical composition of lavender essential oil and its antioxidant activity and inhibition against rhinitisrelated bacteria. African Journal of Microbiology Research. 2010; 4(4) : 309-313. Article Number - AFB8DA511807. URL: http://www.academicjournals.org/journal/AJMR/article-abstract/AFB8DA511807

10. Venskutonis PR, Dapkevicius A, Baranauskiene M. Composition of the essential oil of lavender (Lavandula angustifolia Mill.) from Lithuania. Journal of Essential Oil Research. 1997; 9(1):107-110. DOI:10.1080/10412905.1997.9700727.

11. Tanker N, Koyuncu M, Coşkun M. Farmasötik Botanik. Ank.Ünv. Eczacılık Fak. Yayınları Ders Kitapları No:78. 1998. ISBN No. 975-482-411-8.

12. Smigielelski K, Raj A, Krosowiak K, Gruska R. Chemical composition of the essential oil of Lavandula angustifolia cultivated in Poland. Journal of Essential Oil Bearing Plants. 2008; 12(3):128-136. DOI: 10.1080/0972060X.2009.10643729.

13. Davis PH. Flora of Turkey and the Aegean Islands, Vol. 7. Edinburgh University Press, Edinburgh. 1982. 76 p. URL: http://link.springer.com/article/10.1007\%2FBF02853097

14. Baytop T. Therapy with Medicinal Plants in Turkey (Past and Present). vol. 385. Therapy with Medicinal Plants in Turkey 385. İstanbul: University Press İstanbul. 1984. 316 p. URL: 
https://scholar.google.com.tr/scholar?as_vis=0\&q=baytop, + Therapy + with +Medicinal+Plants + in+Turkey+(Past+and+Present $) \& h l=t r \& a s \_s d t=0,5$

15. Gilani AH, Aziz N, Khan MA, Shaheen F, Jabeen Q, Siddiqui BS, Herzig JW.

Ethnopharmacological evaluation of the anticonvulsant, sedative and antispasmodic activities of Lavandula stoechas L. Journal of Ethnopharmacology. 2000; 71: 161/167.

DOI: $10.1016 /$ S0378-8741(99)00198-1.

16. Rabiei Z, Rafieian-Kopaei M, Mokhtari S, Alibabaei Z, Shahrani M. The effect of pretreatment with different doses of Lavandula officinalis ethanolic extract on memory, learning and nociception. Biomedicine \& Aging Pathology. 2014; 4(1):71-76.

DOI: $10.1016 /$ j.biomag.2013.10.006.

17. Dawson NL, Reinhardt DJ. Microbial flora of inuse, display eye shadow testers and bacterial challenges of unused eye shadows. Appl. and Environ. Microbiol. 1981;42:297-302. URL: http://aem.asm.org/content/42/2/297.short

18. USP. United States Pharmacopeia XXII, US: pharmacopeial convention, Rockville. 1990. URL: http://www.usp.org/.

19. Anelich LE, Korsten L. Survey of microorganisms associated with spoilage of cosmetic creams manufactured in South Africa. Int. J. Cosmet. Sci. 1996;18: 25-40. DOI: 10.1111/j.14672494.1996.tb00133.x.

20. Behravan J, Bazzaz F, Malaekeh P. Survey of bacteriological contamination of cosmetic creams in Iran (2000). Int J Dermatol. 2005; 44: 482-485. DOI: 10.1111/j.1365-4632.2005.01963.x.

21. Darmstadt GL. Oral antibiotictherapy for uncomplicated skin infections in children. Pediatr Infect Dis J. 1997; 16:227-240. URL:

http://journals.Iww.com/pidj/Citation/1997/02000/Oral_antibiotic_therapy_for_uncomplicated .12.aspx

22. Reid FR, Wood TO. Pseudomonas corneal ulser the causative role of contaminated eye cosmetics. Arch. Ophtalmol. 1979; 97:1640-1641. DOI: 10.1001/archopht.1979.01020020208002.

23. Flores M, Morillo M, Crespo ML.Deterioration of raw materials and cosmetic products by preservative resistant microorganisms. Đnt. Biodeterioration and Biodegradation. 1997;40: 157-160. DOI:10.1016/S0964-8305(97)00037-1.

24. Kıvanç M. Kozmetik Ürünlerde Mikrobiyel Kontaminasyon. 2. Kozmetik Kongresi, 17-19 Subat 2012, Antalya. URL: http://kimyakongreleri.org/K2012/K2012-011.pdf

25. Lundov MD, Zachariae C. Recalls of microbiologycally contaminated cosmetics in EU from 2005 to May 2008. Int.J. of Cosmetic Sci. 2008; 30: 471-474. DOI: 10.1111/j.14682494.2008.00475.x

26. Kiselev KV, Dubrovina AS, Veselova MV, Bulgakov VP, Fedoreyev SA, Zhuravlev YN. The rol-B gene-induced over production of resveratrol in Vitis amurensis transformed cells. Journal of Biotechnology. 2007; 128: 681-692. DOI:10.1016/j.jbiotec.2006.11.008.

27. Gomes T, Caponio F, Alloggio V. Phenolic compounds of virgin olive oil: influence of paste preparation techniques. Food Chemistry, 1999; 64: 203-209. DOI:10.1016/S03088146(98)00146-0.

28. Baydar H, Kuleasan H, Kara N, Secilmis-Canbay H, Kineci S. The effects of pasteurization, ultraviolet radiation and chemiclal preservatives on microbial spoilage and scent composition of rose water. Journal of Essential Oil Bearing Plants. 2013; 16(2): 151-160. DOI: 10.1080/0972060X.2013.794043.

29. Cowan MM. Plant Products as Antimicrobial Agent. Clin. Microbiol. Rev. 1999; 12(4):564. URL: http://cmr.asm.org/content/12/4/564.short 
30. Karou D, Nadembega WMC, Ouattara L, Ilboudo DP, Canini A, Nikiema JB, Simpore J, Colizzi V, Traore AS. African Ethnopharmacology and New Drug Discovery. Medicinal and Aromatic Plant Science and Biotech. 2007. URL:

http://citeseerx.ist.psu.edu/viewdoc/download?doi=10.1.1.525.7636\&rep=rep1\&type=pdf

31. Taguri T, Tanaka T, Kouno I. Antimicrobial Activity Of 10 Different Plant Polyphenols Against Bacteria Causing Food-Borne Disease. Biol.Pharm .Bull. 2004; 27(12):1965-1969. DOI: $10.1248 /$ bpb. 27.1965

32. Whitehead DC, Dibb H, Hartley RD. Phenolic Compounds in Soil as Influenced by the Growth of Different Plant Species. Journal of Applied Ecology. 1982; 19:579-588. DOI: $10.2307 / 2403490$.

33. Kang MS, Oh JS, Kang IC, Hong SJ, Choi CH. Inhibitory effect of methyl gallate and gallic acid on oral bacteria. The Journal of Microbiology. 2008; 46(6), 744-750. URL: http://link.springer.com/article/10.1007/s12275-008-0235-7

34. Hammer KA, Carson CF, Riley TV. Antimicrobial activity of essential oils and other plant extracts. J. Appl. Microbiol. 1999;86:985-990. DOI: 10.1046/j.1365-2672.1999.00780.x

35. de Rapper S, Kamatou G, Viljoen A, van Vuuren S. The in vitro antimicrobial activity of Lavandula angustifolia essential oil in combination with other aroma-therapeutic oils. J. Evid. Based Complement. Altern. Med., 2013; 2013:1-24. DOI: 10.1155/2013/852049.

36. Park SN, Lim YK, Freire MO, Cho E, Jin D, Kook JK. Antimicrobial effect of linalool and aterpineol against periodontopathic and cariogenic bacteria. Anaerobe. 2012;18(3), 369-372. DOI:10.1016/j.anaerobe.2012.04.001.

37. Hammer KA, Carson CF. Antibacterial and antifungal activities of essential oils. H. Thormar (Ed.), Lipids and essential oils as Antimicrobial agents, Wiley, UK. 2010; 256-306. DOI: 10.1002/9780470976623.ch11.

38. Lang G, Buchbauer G. A review on recent research results (2008-2010) on essential oils as antimicrobials and antifungals. A review. Flavour and Fragrance Journal. 2012; 27(1), 13-39. DOI: $10.1002 / \mathrm{ffj} .2082$.

39. Nelson RRS. In-vitro activities of five plant essential oils against methicillin-resistant Staphylococcus aureus and vancomycin-resistant Enterococcus faecium. Journal of Antimicrobial Chemotherapy. 1997; 40(2): 305-306. DOI: 10.1093/jac/40.2.305.

40. Adam K, Sivropoulou A, Kokkini S, Lanaras T, Arsenakis M. Antifungal activities of Origanum vulgare subsp. hirtum, Mentha spicata, Lavandula angustifolia, and Salvia fruticosa essential oils against human pathogenic fungi. Journal of Agricultural and Food Chemistry. 1998; 46(5): 1739-1745. DOI: $10.1021 /$ jf9708296.

41. Hammer KA, Carson CF, Riley TV. In-vitro activity of essential oils, in particular Melaleuca alternifolia (tea tree) oil and tea tree oil products, against Candida spp. Journal of Antimicrobial Chemotherapy. 1998; 42(5): 591-595. DOI: 10.1093/jac/42.5.591.

42. Shin S, Lim S. Antifungal effects of herbal essential oils alone and in combination with ketoconazole against Trichophyton spp. Journal of Applied Microbiology. 2004; 97(6): 12891296. DOI: $10.1111 / \mathrm{j} .1365-2672.2004 .02417 . x$.

43. Mayaud L, Carricajo A, Zhiri A, Aubert G. Comparison of bacteriostatic and bactericidal activity of 13 essential oils against strains with varying sensitivity to antibiotics. Letters in Applied Microbiology. 2008; 47(3):167-173. DOI: 10.1111/j.1472-765X.2008.02406.x.

44. Lodhia $\mathrm{MH}$, Bhatt KR, Thaker VS. Antibacterial activity of essential oils frompalmarosa, evening primrose, lavender and tuberose. Indian Journal of Pharmaceutical Sciences. $2009 ; 71(2): 134-$ 136. DOI: $10.4103 / 0250-474 X .54278$.

45. Agarwal V, Lal P, Pruthi V. Effect of plant oils on Candida albicans. Journal of Microbiology, Immunology and Infection. 2010;43(5):447-451. DOI:10.1016/S1684-1182(10)60069-2. 
46. Sokovi 'c M, Glamo `clija J, Marin P. D. Antibacterial effects of the essential oils of commonly consumed medicinal herbs using an in vitro model. Molecules. 2010;15: 7532-7546. DOI: 10.3390/molecules15117532.

47. Tsai TH, Tsai TH, Wu WH, Tseng JTP, Tsai PJ. In vitro antimicrobial and anti-inflammatory effects of herbs against Propionibacterium acnes. Food Chemistry. 2010; 119(3): 964-968. DOI: 10.1016/j.foodchem.2009.07.062.

48. Alexopoulos A, Kimbaris AC, Plessas S. Antibacterial activities of essential oils from eight Greek aromatic plants against clinical strains of Staphylococcus aureus. Anaerobe. $2011 ; 17 ; 399-$ 402. DOI:10.1016/j.anaerobe.2011.03.024. 


\title{
Türkçe Öz ve Anahtar Kelimeler \\ Fitokozmetik Tür olarak Lavandula angustifolia Mill.'in Kimyasal Karakterizasyonu ve Kozmetik Ürünlerde Antimikrobiyal Etkisinin Incelenmesi
}

\author{
Aslıhan Cesur Turgut, Fatih Mehmet Emen, Hale Seçilmiş Canbay, Ruken Esra \\ Demirdöğen, Neslihan Çam, Derya Kılıç, Tuncay Yeşilkaynak
}

Öz: Burdur-Örtülü'de yetişen Lavandula angustifolia türünden elde edilen ekstraktların bileşimi HPLC ve GC-MS analizleriyle belirlenmiştir ve L. angustifolia'nın esansiyel yağındaki antimikrobiyal etki araştırılmıştır. L. angustifolia'nın kurutulmuş çiçekleri ekstrakte edilmiş ve esansiyel yağı geri kalan kısmından damıtılmıştır. Ekstrakttaki çeşitli fenolik bileşikler HPLC ile kantitatif olarak belirlenmiştir. Kantitatif olarak kafeik asit, rosmarinik asit ve 4-hidroksibenzoik asitler, bu sırada azalacak şekilde, en bol bulunan fenolik asitler olarak bulunmuştur. GC-MS analizinde 31 farklı bileşik belirlenmiştir: Linalool ve linalil asetat en yüksek derişimlere sahiptir. L. angustifolia'nin esansiyel yağının antimikrobiyal aktivitesi, kozmetik ürünlerde en çok rastlanan mikroorganizmalara karşı tespit edilmiştir (Candida albicans, Staphylococcs aureus, Pseudomonas aeruginosa ve Aspergillus brasiliensis). L. angustifolia'nın esansiyel yağının 14.günden itibaren mikroorganizmalar tarafından oluşturulan kirliliği tamamen giderdiği görülmüştür. Sonuçlara göre, L. angustifolia'nın esansiyel yağının yukarıda bahsedilen mikroorganizmalara karşı başka bir koruyucu madde gereksinimi olmaksızın, kozmetik ürünlerde doğrudan veya dolaylı olarak kullanılabileceği anlaşılmaktadır.

Anahtar kelimeler: Lavandula angustifolia Mill.; kozmetik ürünler; fenolik bileşikler; esansiyle yağ; antimikrobiyal aktivite.

Sunulma: 04 Temmuz 2016. Düzeltme: 24 Kasım 2016. Kabul: 25 Kasım 2016. 